\title{
«ЧЕЛОВЕК ВОЙНЫ» В КОНТЕКСТЕ ВОЕННОЙ ИСТОРИИ КРЫМА 1941-1944 ГГ., ИЛИ ОБОРОНА СЕВАСТОПОЛЯ - ИСТОРИЯ ЗАЩИЩАЮЩИХСЯ
}

\author{
О. Г. Жукова \\ (Московский гуманитарный университет)
}

Аннотация: Статья посвящена военной истории Крыма, в частности, обороне Севастополя в годы Великой Отечественной войны. Автор отмечает важность историософского осмысления истории Великой Отечественной войны.

Подготовлено на основе доклада автора на Всероссийской научной конференции «Военная история России», которая прошла в Московском гуманитарном университете 25 апреля 20162.

Ключевые слова: Великая Отечественная война; Вторая мировая война; история повседневности; история войн; военная история; Крым; оборона Севастополя; человек войны; человек фронта; антропология войны

\section{"MAN AT WAR» IN THE CONTEXT OF THE MILITARY HISTORY OF THE CRIMEA, 1941-1944, OR THE DEFENSE OF SEVASTOPOL - THE STORY OF ITS DEFENDERS}

\author{
O. G. Zhukova \\ (Moscow University for the Humanities)
}

Abstract: The article is devoted to the military history of the Crimea, in particular, to the defense of Sevastopol during the Great Patriotic war. The author notes the importance of historiosophical understanding of the history of the Great Patriotic war.

This article is based on the paper presented at "The military history of Russia" conference, which was held at Moscow University for the Humanities on April 25, 2016.

Keywords: Great Patriotic war; World War II; history of everyday life; history of warfare; military history; Crimea; defense of Sevastopol; "man of the front"; "man at war"; anthropology of war

Военную историю принято определять, как историю войн, которые велись известным народом или государством или происходивших в какуюнибудь определенную историческую эпоху. Или, как историю какой-либо 
одной войны или даже отдельной кампании. Под военной историей понимают также науку о происхождении, строительстве и действиях вооруженных сил (воинских формирований) государств (народов) мира.

При этом упускается из вида, что военная история - это и история тыла воюющей страны, история ее повседневности, ее быта. Между тем, без крепкого тыла невозможна победа на фронте, что особенно ярко показала история Великой Отечественной войны, после которой труженики тыла были приравнены к ветеранам войны, поскольку, как сказал поэт: «Из одного металла льют медаль за подвиг и за труд».

Пожалуй, так же не хватает полноты содержания активно вводимым в научный оборот понятиям «человек войны», «человек на войне» (Сенявская, 1997), подразумевающим непосредственно и только комбатанта, т. е. лицо, принимающее непосредственное участие в боевых действиях (от фр. combatant - «сражающийся»). Представляется, что научное наполнение этих важнейших и необходимых для военной истории терминов следовало бы расширить, «разделив» «человека войны» на отдельные «ипостаси» - «человек фронта», «человек тыла», «человек оккупации». Подумать о разнице положения в контексте военной истории, скажем, «человека оккупации» сопротивляющегося или «человека оккупации» смирившегося, сломившегося, принявшего новый оккупационный порядок или даже по разным причинам пошедшего в услужение врагу.

В этом смысле неоценимый историософский материал представляет нам история Крымского полуострова в годы Великой Отечественной войны, где одновременно можно изучать во взаимодействии все эти столь разные типы «человека войны». Но Крым, оказавшийся после развала СССР за пределами российских границ, как будто бы выпал из общего контекста войны, и эти героические страницы нашей истории остались на периферии научных интересов отечественных историков. Было время, когда главнейшие вехи войны сводились для нас к битве за Москву, блокаде Ленинграда, Сталинградской битве, Орловско-Курской дуге, освобождению Восточной Европы и взятию Берлина. Сегодня мы стали свидетелями не только возвращения Крыма с точки зрения физической и экономической географии, но и, можно сказать, наблюдаем его ментальное возвращение, через интерес к его истории, через возвращение имен исторических персонажей, связанных с этой героической пядью российской земли. И история Крыма, обороны Севастополя становится важной страницей не только в контексте истории Великой Отечественной войны, но и всей Второй мировой войны в целом.

Справедливости ради отметим, что историография Крыма изредка пополнялась и в постсоветские времена. Особенно хочется отметить такое издание, как «Москва-Крым: Историко-публицистический альманах. 
Специальный выпуск: Крым в Великой Отечественной войне: дневники, воспоминания, исследования», вышедшее при финансовой поддержке Департамента международных связей и Комитета общественных связей города Москвы в 2003 г. (Москва-Крым ..., 2003). В нем опубликованы документы личного характера крымчан, волею судьбы оказавшихся по разные стороны фронта. В героически обороняющемся Севастополе, в партизанском отряде, в оккупированном Симферополе и других городах и селениях Крыма. Сколь много отличий в их повседневности, сколь много общего в их личной драме... Этим и уникальна история Крыма периода Великой Отечественной войне, именно поэтому дает она богатейшую информацию к историософским размышлениям, обобщениям, заключениям.

До сих пор популярный французский писатель Александр Дюма, побывавший в России в 1858-1859 гг., рассказывал о том, что более всего потрясло его одно непроизносимое для иностранца русское слово - «защищающиеся». Представим, сколькими буквами латинского алфавита надо написать его транскрипцию! Осознал ли тогда знаменитый француз, что выделил из услышанного русского контекста слово удивительным образом отражающее суть русского взгляда на мир? Министерством обороны, а вовсе не нападения называется главное ведомство, творящее военную историю России, руководящее лавиной «людей войны», становящимися таковыми вне зависимости от ношения военной формы и своего место в едином народном фронтовом строю...

O «паническом отступлении» и даже «драпе» Красной Армии от советской границы летом 1941 г., о «хаосе и неразберихе», якобы царящей повсеместно, о «растерянности» руководства страны модно говорить сегодня, смакуя подробности. А свидетельства, не укладывающиеся в эту простую схему, - подвергать сомнению, считать «пропагандой». Да, Совинформбюро (информационный и пропагандистский орган, созданный в СССР в первые дни войны) давало совсем другую картину тех первый дней и, как оказалось впоследствии, не лгало, хотя иногда не договаривало, чтобы действительно не допустить паники на фронте и в тылу в столь драматический для общества момент.

Сводки первых дней войны скупо сообщают о бомбардировках десятков наших городов. И - неожиданно, уже 24 июня информируют о советских (!) бомбардировках Данцига, Кенигсберга, Люблина, Варшавы... «В ответ на двукратный налет на Севастополь немецких бомбардировщиков с территории Румынии советские бомбардировщики трижды бомбардировали Констанцу и Сулин. Констанца горит» (Совинформбюро ..., Электр. ресурс). И еще через два дня, 26 июня: «Наша авиация в течение дня бомбардировала Бухарест, Плоешти и Констанцу. Нефтеперегонные заводы в районе Плоешти горят» (там же). Это официальное известие молние- 
носно породило слухи в народе, распространившиеся до самой столицы: «Красная Армия разбомбила и взяла Варшаву, Кенигсберг и ведет успешное наступление на Румынию», а «Риббентроп застрелился» (Российский государственный архив социально-политической истории - далее РГАСПИ, Ф. 17, ОП. 125, Д. 44.).

А что же происходило на самом деле? В те страшные дни именно из Крыма, из Севастополя, пришли известия, обнадежившие всю страну, ставшие первыми ласточками будущих, нескорых еще побед. Подробности были известны не всем. Главный редактор фронтовой газеты «Красный черноморец» Павел Мусьяков в дневнике раскрывает их. Оказывается, в ответном ударе по врагу участвовала не только авиация, но и Черноморский флот: «Вчера вернулись корабли из операции по обстрелу Констанцы с моря. Сотни снарядов были посланы по городу, порту и нефтяным бакам. Черный дым нефтяных пожаров долго стоял на горизонте, когда наши корабли уже были за десятки миль от румынских берегов» (Мусьяков, 2003: 19).

Во время опасного рейда к вражескому берегу на одном из наших кораблей лопнули трубки в двух котлах. На охлаждение раскаленной топки не было времени! И тогда котельные машинисты Капров и Гребенников надевают асбестовые костюмы, обматывают головы мокрыми бинтами и в течение получаса работают в настоящем пекле, вынимают неисправные трубки, заглушают их в гнезда. Несколько раз теряют сознание, их вытаскивают, обливают водой, приводят в чувство «ободряющей жидкостью», дают отдышаться... И снова - в топку, вооружившись молотками и зубилами. Наконец, неисправность устранена, и наш лидер на полном ходу уходит к родной гавани (там же).

...Гитлер собирался занять Севастополь летом 1941 г. Но и этот, черноморский блицкриг был сорван героями-севастопольцами, задержавшими здесь врага на долгие восемь месяцев. Оборона города продолжалась 250 дней - с 30 октября 1941 г. по 4 июля 1942 г.

Тогда, в 1941-м, стойкость защитников Севастополя, оттянувших значительные силы противника на себя, способствовала разгрому немецких войск под Москвой. Приказ А. Гитлера от 21 августа 1941 г. ориентировал немецкие войска: «Важнейшей целью до наступления зимы считать не захват Москвы, а захват Крыма, промышленных и угольных районов на Донце и лишение русских возможности получения нефти с Кавказа...» (На Киевском направлении, Электр. ресурс).

Но «город русских моряков» Севастополь продолжал обороняться, даже оказавшись в кольце врагов. Говорят, тогда же фюрер назвал Крым «непотопляемым советским авианосцем, атакующим немецкую нефть...» Да, теперь уже немецкую, а вовсе не румынскую... 
Чтобы огромная воюющая страна жила не слухами, а правдивой информацией с полей сражений выехали на фронт сотни «бойцов культурного фронта». И уже совсем скоро во фронтовой редакции «Красного черноморца» появились откомандированные из столицы «братья-писатели», журналисты, художники, призванные создавать историческую летопись героического сопротивления крымчан врагу. Не готовыми к суровым военным будням «глубоко штатскими людьми» показались они вначале главреду Мусьякову, про себя прозвавшему их «очкастыми». Но вскоре выяснилось, что были они отчаянными смельчаками, и, казалось, более других в те суровые дни верящими в грядущую нашу Победу. Писатели: Петр Гаврилов (автор чудесной повести для детей «Егорка» - про медвежонка, подружившегося с моряками), Василий Ряховский (автор исторических романов «Родная сторона» и «Евпатий Коловрат»), Игнат Ивич (автор научно-популярных книг для детей) и Август Явич, который после войны создаст свою «Севастопольскую повесть». Поэт Лев Длигач, известный детскими стихами, и поэт-сатирик Ян Сашин. Художники Федор Решетников (будущий автор знаменитых картин «Опять двойка», «Прибыл на каникулы», «Достали языка!», «За мир!») и Леонид Сойфертис (автор ярких карикатур для журнала «Крокодил»)...

Боевые операции, героические поступки, примеры несгибаемой воли севастопольцев и их фронтовой быт, трогательный в своей простоте, стали основными темами репортажей кинооператоров: Д. Рымарева, Ф. Короткевича, А. Кричевского, Г. Донца, А. Смолки, В. Микоши. И не раз слышали они во время боев от героев своих киноочерков слова, полные надежды: «Братцы, нас снимают. Навсегда останемся живыми»... И вправду, сколько потом родных и близких видела их на экране... еще живыми и молодыми.

Два документальных фильма, которые увидела вся страна, были сняты в Севастополе режиссером В. Беляевым за годы войны. В период обороны города, 1942 г. - «Черноморцы», в дни его освобождения, 1944 г. «Битва за Севастополь».

«Враг обрушивает тонны металла, он разрушает великолепные здания - жилые дома, научные институты, храмы, памятники искусства... Но кончилась бомбежка, затих артиллерийский обстрел, и вновь ожили бульвары и улицы. Молодая мать катит ребенка в колясочке, боец наводит блеск на сапоги у уличного чистильщика. Ребята маршируют в ногу с проходящим на фронт отрядом краснофлотцев и с непередаваемой гордостью красуются в своих по-морски сшитых бушлатиках и бескозырках. ...В расположенных вблизи Севастополя развалинах древнего пещерного города, каменоломнях Инкермана, под естественным укрытием из скал и каменных нагромождений идет напряженная работа разместившихся там 
оборонных заводов, хлебопекарен, больниц. Там куется оружие борьбы и победы, туда приводят раненых, и в подземных госпиталях их оперируют и выхаживают», (Смирнов, 1947: 39) - передавал атмосферу воюющего города фильм «Черноморцы».

В дни особенно ожесточенных налетов оператор Владислав Микоша, находясь на катере, снимает советский миноносец, с расстояния 40-50 метров. Катер беспомощно кружит около, а до 70 вражеских бомбардировщиков пикируют на уже горящий миноносец. Наши моряки продолжают стрелять из зенитных орудий, даже когда одежда на них загорелась и даже когда судно начало тонуть, а вода дошла им до пояса. Последние кадры: над водой виднеется нос миноносца и пробитый флаг...

И, пожалуй, неслучайно, что в кинолетопись обороны Севастополя вписал множество ярких страниц бесстрашный спецкор «Правды» с «ласковой» фамилией Микоша, производной от имени Миколай, Николай, ведь Святитель, носящий это имя, издавна почитается покровителем моряков.

Отец Владислава Владиславовича Микоши был капитаном дальнего плавания. Морские дали манили и сына, родившегося и выросшего в Саратове, десятилетним пацаном переплывавшего великую реку, увлекавшегося и воздушной акробатикой, и живописью, и музыкой, и кино. Он даже освоил ремесло киномеханика. А поступать решил волжанин в 1927 г. все же в Ленинградскую мореходку. Но не прошел медицинскую комиссию, т.к. к досаде своей накануне сильно простудился. Вернулся в родной Саратов, где его ждала прежняя должность в кинотеатре «Искра». А через два года Владислав стал уже учащимся Государственного кинотехникума в Москве (ныне - Всесоюзный государственный институт кинематографии), который окончил в 1934 году. Это именно он снимал взрыв Храма Христа Спасителя и открытие ВСХВ (ВДНХ), эпопею спасения челюскинцев и перелеты Чкалова и Громова в Америку, приезды в Москву мировых знаменитостей - Бернарда Шоу, Ромена Роллана, Анри Барбюса. Командированный на Черноморский флот, он смог надеть, наконец, черную морскую форму и снимал оборону Одессы, Севастополя, а потом и - поверженный Берлин.

Режиссер киноэпопеи «Великая Отечественная» Лев Данилов писал: «Про военные съемки Микоши справедливо сказать, что они сразу и быт и поэзия... На пленке кинодокументов, снятых Микошей, всегда присутствует температура события».

Все долгие севастопольские дни и месяцы «температура события» в городе была накаленной, и этот накал заметен не только в кадрах кинохроники, но и на фронтовых зарисовках художника Леонида Сойфертиса.

В № 36 за 1944 г. журнал «Крокодил» опубликовал «Севастопольский альбом» своего постоянного автора - художника Леонида Сойфертиса. 
Уроженец местечка Ильинцы Винницкого уезда Подольской губернии, столь далекого от моря, волею судеб воспел в своем творчестве моряков Одессы, Севастополя, Новороссийска. Карикатурист, прибывший из столицы на Черноморский флот в первые дни войны, рисовал карикатуры на злобу дня для газеты «Красный черноморец», но повседневная жизнь героического города давала столько пищи для творческих раздумий, что вскоре художник открыл для себя новый жанр. Позже специалисты отметят в его зарисовках времен обороны Севастополя особый подход к разрешению темы - «подход рассказывания». И рассказывали они зрителю «при вдумчивом восприятии... о всенародности войны, о той горячей любви, которой окружала страна свои героические Армию и Флот» (Изобразительное искусство ... 1951: 49-51). Отметили критики и особое «уменье распознать в малом, как будто случайном, даже смешном эпизоде большое, величественное время»... (там же).

В графических рисунках Сойфертиса, изображающих быт войны, нет ни одного убитого и никто не стреляет, а люди, показанные в обыденных ситуациях, кажется, даже и не чувствуют себя героями.

Сам художник удивлялся этому ставшему обыденным героизму. Девушка-санитарка, переоделась к празднованию 8-го марта в красное гипюровое платье с белым бантом: «Она пришла в шинели, и за сапогом у нее была ложка, а передовые позиции совсем рядом, и где она там держит чемоданчик с платьем - одному богу известно» (там же).

«В Севастополе, - рассказывал художник, - я жил в центре города, но достаточно было выйти из дома, чтобы почувствовать себя на фронте. Меня поражала непрерывность жизни, сохраняющейся везде, несмотря на ужас беспрерывных бомбежек и беспрерывных боев. Помню, на аэродроме увидел летчика, бреющегося перед боевым вылетом с хладнокровием человека, уверенного в возвращении. Или такая деталь: в окопе рядом с минометом стоит балалайка. Помню почтальоншу, которая разносила письма, пробираясь через только что разрушенное здание в бомбоубежище; она знала в каком бомбоубежище находится ее адресат. Мне передалась уверенность всех в победе, и хотелось рассказать о том, что я вижу, оптимистически, весело» (там же: 117-118).

На рисунке «Некогда» - двое мальчишек-чистильщиков обуви на ходу чистят ботинки бравому матросу. Он широко расставил ноги и рукой облокотился на театральную тумбу, - спешит в бой! Другой матрос застыл перед фотоаппаратом фотографа прямо в воронке от бомбы, среди развалин - «Фотография на партдокумент». А третий моряк в могучих руках, которые, возможно, еще минуту назад душили врага, осторожно держит котенка - «Котенка нашли»! Малышня лихо и весело работает вениками, подметая лестницу, только вот не ведет она в дом, а в пустом 
дверном проеме - небо - «Уборка лестницы». На другом рисунке малыши сидят на изгороди и смотрят, как проходит мимо отряд моряков, а над их головами точно так же, рядком, сидят на проволоке ласточки - «Матросы идут»... Несколько едва уловимых штрихов и зарисовки наполняются воздухом, движением, солнцем, надеждой...

О том же обыденном героизме самого художника рассказывал командир части, при которой находился Л. Сойфертис в газете «Литература и искусство». Оказывается, он лежал рядом с матросом-пулеметчиком под немецким огнем, чтобы запечатлеть, «какое бывает выражение лица у человека, когда он стреляет по фашистам» (там же: 80).

...И все-таки, несмотря на массовый героизм севастопольцев, город, после появления на горах немецких дальнобойных пушек, изменивших расклад сил, пришлось оставить в июле 1942 г. Трудно, страшно, с очень большими потерями. Вспомним, в это время немцы стоят у стен Сталинграда, на подступах к нефтяным районам Кавказа.

...С 8 апреля по 12 мая 1944 г. войска 4-го Украинского фронта и Отдельной Приморской армии во взаимодействии с Черноморским флотом и Азовской военной флотилией провели операцию по освобождению Крыма, начавшуюся с отважного десанта Отдельной Приморской армии на Керченский полуостров.

Стремительным было освобождение нашими войсками крупнейших городов Крыма - Феодосии, Евпатории, Симферополя. И мощной волной накатывают они на Севастополь. Три полосы железа и бетона, сведенные в мощные узлы сопротивления с разветвленной системой противотанковых и противопехотных заграждений окружали город. Сапун-гора главенствующая высота, с обрывистыми скатами, закованными в железобетон с четырехъярусной системой траншей, опутанных инженерными сооружениями.

Штурм начался 7 мая ударами нашей бомбардировочной авиации. Затем вступила артиллерия, разрушившая ДоТы на склонах горы. В бой пошли бойцы штурмовых групп с противотанковыми ружьями, на себе тащили по горным склонам пушки - били по амбразурам ДОТов. За ними поднималась к вершине горы пехота...

...Среди передовых частей, ворвавшихся в Севастополь, находились и кинооператоры: В. Микоша, Д. Шоломович, И. Аронс, В. Афанасьев, Г. Донец, Д. Каспий, В. Килосанидзе, Л. Котляренко, Ф. Овсянников, Н. Петросов, М. Пойченко, А. Смолка, В. Сущинский, Г. Хнкоян и др. Снятые ими кинокадры боев и войдут в фильм «Битва за Севастополь».

С вершины горы, на которой расположено старое Итальянское кладбище, кинооператор Микоша снимает танковый бой в Инкерманской долине, видит, как спешно уходят в море немецкие корабли. А на Графской 
пристани, за неимением красного флага, краснофлотцы привязывают к флагштоку снятую с себя тельняшку и бескозырку.

Эти кадры станут эффектной концовкой фильма, сопровождающейся голосом за кадром: «Там, где в начале войны немцам понадобилось двести пятьдесят дней, чтобы преодолеть оборону советских воинов, там сейчас Красная Армия сломила немецкое сопротивление за пять дней».

Война оставила нам, исследователям, разнообразный источниковедческий материал, и это отнюдь не только архивные документы и воспоминания очевидцев. Это еще и кадры кинохроники, фронтовые газеты, зарисовки художников, и даже личные воспоминания о пережитом в годы, когда давно уже отгремели последние залпы войны.

Мой старший коллега - доктор исторических наук, профессор Мансур Михайлович Мухамеджанов служил в Севастополе срочную службу в 1955-1959 гг. Казалось, город-герой совсем к этому времени уже залечил свои боевые раны. Но однажды в горах, как вспоминал М. М. Мухамеджанов, молодые моряки, находясь в самоволке, обнаружили территорию, опутанную проржавевшей колючей проволокой, пробрались через нее, и взору их открылась ужасная картина - полуистлевшие трупы расстрелянных лежали горой... Буквально бежали оттуда, потрясенные увиденным. А однажды на учениях, они, окапываясь, обнаружили свинцовую полоску, скрученную, словно древняя грамота, развернули и прочли: «Мы стоим здесь до конца!» И - короткий список фамилий... Неожиданная находка была передана в музей. И именно поэтому послевоенное уже поколение моряков с особым чувством сопричастности к героическим защитникам города пело всем строем, маршируя в Театр им. Луначарского, фронтовую песню неизвестного автора, далекую от литературного совершенства, но такую важную для исторической эстафеты поколений: «С Черного - я, ты - из далека,/Ты приехал с Дальнего Востока./ Мы с тобой вдвоем/ Крепко немцев бьем, /Защищая город Севастополь./ Ждут нас впереди тяжкие бои./ /Впереди еще немало боя/ Русским был и есть/ Севастополь наш. / Севастополь - город Черноморья!»

Самое поучительное и трогательное для нас, потомков, - это отношение оставшихся в живых к памяти павших. Уже 17 октября 1944 г. был открыт на Сапун-горе памятник-обелиск советским воинам, павших в боях за освобождение города.

\section{СПИСОК ЛИТЕРАТУРЫ}

Изобразительное искусство в годы Великой Отечественной войны (1951). М. : Академия художеств СССР. 308 с.

Москва-Крым (2003): Историко-публицистический альманах. Специальный выпуск: Крым в Великой Отечественной войне: дневники, вос- 
поминания, исследования Вып. 5. М. : Московедение. 472 с.

Мусьяков, П. И. (2003) Севастопольские дни // Москва-Крым: Историко-публицистический альманах. Специальный выпуск: Крым в Великой Отечественной войне: дневники, воспоминания, исследования Вып. 5. М. : Москвоведение. 472 с.

На Киевском направлении [Электронный ресурс] // Самиздат. URL: http://samlib.ru/a/alt/r14.shtml (дата обращения: 07.03.2016).

Сенявская, Е. С. (1997) Человек на войне. Историко-психологические очерки. М. : Институт российской истории РАН. 232 с.

Смирнов, В. (1947) Документальные фильмы о Великой Отечественной войне. М. : Госкиноиздат.

Совинформбюро. Оперативные сводки за 1941 год [Электронный ресурс] // Великая Отечественная война. Интернет-проект. URL: http://19411945.at.ua/forum/29-291-1 (дата обращения: 07.03.2016).

Дата поступления: 15.06.2016 г.

Жукова Ольга Германовна - кандидат исторических наук, доцент кафедры истории МосГУ, член Союза писателей России и Союза журналистов Москвы. Адрес: 111395, Россия, г. Москва, ул. Юности, д. 5. Тел.: + 7 (499) 37455 81. Эл. адрес: letchikova@mail.ru

Zhukova Olga Germanovna, Candidate of History, Associate Professor, Department of History, Moscow University for the Humanities; Member, Russian Union of Writers, Union of Journalists of Moscow. Postal address: 5 Yunosti St., 111395 Moscow, Russia. Tel.: + 7 (499) 374-55-81.E-mail: letchikova@mail.ru 